\title{
Research Article OSMOTIC DEHYDRATION PROCESS FOR PRESERVATION OF FIG FRUIT AND ITS QUALITY EVALUATION
}

\author{
LAVANYA K. ${ }^{1}$, UPENDAR K. ${ }^{2}$, ADAMALA SIRISHA ${ }^{\star *}$, BANDHU S. JEENA², KUMAR S. ${ }^{2}$ AND REDDY S. PRAKASH ${ }^{2}$ \\ 'Department of Applied Engineering, Vignan's Foundation for Science, Technology and Research, Vadlamudi, Guntur, Andhra Pradesh 522213, India \\ ${ }^{2}$ Agricultural Engineering, College of Agricultural Engineering, Acharya N.G. Ranga Agricultural University, Guntur, Bapatla, Andhra Pradesh 522101, India \\ ${ }^{*}$ Corresponding Author: Email-sirisha.cae@gmail.com
}

\section{Received: January 27, 2018; Revised: February 04, 2018; Accepted: February 06, 2018; Published: February 15, 2018}

\begin{abstract}
In this study, different experiments were conducted to characterize the osmotic dehydration of Fig fruit with respect to drying behavior. The quality of dehydrated Fig fruit slices was evaluated with the syrup concentrations (30,40 and $50 \mathrm{\circ Bx}$ ) and time of immersion (1 hr interval up to 6 hrs). The fruit to solution ratio was taken as 1:5 (w/v). The maximum and minimum amount of weight reduction of $182-63 \mathrm{~g}$ and $196-68 \mathrm{~g}$ was found at higher concentrations $50{ }^{\circ} \mathrm{Bx}$ and $30{ }^{\circ} \mathrm{Bx}$, respectively. The maximum amount of solid gain and water loss of $11.72 \%$ and $20.72 \%$ was found at $50{ }^{\circ} \mathrm{Bx}$ and minimum amount of solid gain and water loss of $5.64 \%$ and $7.64 \%$ was found at $30 \mathrm{\circ B}$, respectively. Overall results indicated that the water loss and solid gain were increased with the increase in immersion time and with different sugar solution concentrations. The moisture content (\%) and drying rate were decreased with increase in drying time.
\end{abstract}

Key Words- Osmotic dehydration, Water loss, Solid gain, Weight reduction, Fig fruit

Citation: Lavanya K., et al., (2018) Osmotic Dehydration Process for Preservation of Fig Fruit and its Quality Evaluation. International Journal of Agriculture Sciences, ISSN: 0975-3710 \& E-ISSN: 0975-9107, Volume 10, Issue 3, pp.-5099-5101. DOl: http://dx.doi.org/10.9735/0975-3710.10.3.5099-5101

Copyright: Copyright@2018 Lavanya K., et al., This is an open-access article distributed under the terms of the Creative Commons Attribution License, which permits unrestricted use, distribution and reproduction in any medium, provided the original author and source are credited.

Academic Editor / Reviewer: Abhishek Raj, Mehul Patel, Sahar A A Malik Al-saadi

\section{Introduction}

Fig (Ficuscarica) is a deciduous fruit tree grows in tropical and subtropical region of India. They grow well in several states including Karnataka, Tamil Nadu, Maharashtra, Gujarat and Uttar Pradesh. Though there are approximately 800 varieties of Figs in the world, the 'Poona' is the most popular cultivar in India [1] Fig is commonly consumed as fresh or dried. Finding fresh Figs is difficult on account of the fruit's sensitive skin and high perish ability. Fig season occurs twice a year: the first session is from May-June and second is December through January. Figs are an excellent source of minerals, vitamins, iron and dietary fiber; they are free from fat and cholesterol and contain a high amount of amino acids. Nutritionally, dried Figs provide a high quantity of calcium, potassium and dietary fiber vs. other common fruits [2].

Drying or dehydration should be carried out to increase its shelf life but challenge in fruitsand vegetables drying are to reduce the moisture content of the product to a level where microbiological growth will not occur and simultaneously keep the high nutritive value [3]. Tray drying brings the product to undesirable changes in colour, texture, flavor and loss in nutritive value. Hence, a new method of drying in combination of osmosis could be a good solution. Osmotic dehydration is effective even at ambient temperature, so that damage of texture, colour, and flavor of food from heat are minimized. The resulting product has generally better quality than the dried one without pretreatment. The present investigation was carried out to study the effect of tray drying, osmotic solute, solute concentration, immersion time, temperature on the effectiveness of osmotic dehydration of Figs [4].

\section{Materials and Methods}

Fresh Fig fruits were procured from market with an initial moisture content of $83.79 \%$. Healthy and defects free Figs were sorted and selected for conducting experiment (Osmotic dehydration). Osmotic dehydration is a method for the partial dehydration of water-rich foods, such as fruits and vegetables, by immersing them in a concentrate solution of sugar or salt. It results in two simultaneous crossed flows: a water outflow, from the food to the solution and a solute inflow from the solution into the food. The rate of water loss during osmotic dehydration depends upon the solution concentration, immersion time, solution temperature, sample to solution ratio and agitation or circulation of osmotic solution. Sugars were used as osmotic agents to prepare osmotic solution of different concentrations of sugar (30, 40 and $\left.50^{\circ} \mathrm{Bx}\right)$. Osmotic solution was prepared by dissolving calculated amount of sugar in distilled water so as to obtain required concentration of osmotic solutions. The selected variety of Figs was washed with water to remove unwanted material like dust, dirt, and surface adhering material. The Fig bulbs were sliced with a knife manually of approximately $10 \pm 1 \mathrm{~mm}$ thickness. Each $200 \mathrm{~g}$ weight of Fig fruit slices sample was taken and then individually marked by using different colour threads [5].

In osmotic dehydration the prepared samples (Fig fruit slices) were weighed approximately $200 \mathrm{~g}$ for every experiment and immersed in sugar (30, 40 and $50^{\circ} \mathrm{Bx}$ ) contained in a $1000 \mathrm{ml}$ steel container. The container was placed at constant ambient temperature of $30^{\circ} \mathrm{C}$. The solution in the beakers was manually stirred at regular intervals to maintain uniform temperature $\left(30^{\circ} \mathrm{C}\right)$. Every concerned sample was removed from each container at hourly interval up to $6 \mathrm{~h}$ and placed on tissue paper for removal of surface moisture and to eliminate excess solution from the surface before weighing. Finally, the samples were weighed and their moisture contents were determined [6].

The independent variables considered for the experiments are Osmotic agent (sugar), Osmotic Sugar solution concentration (30, 40 and 50\%), Size of sample (10 mm thickness), Osmotic solution temperature $\left(30^{\circ} \mathrm{C}\right)$, Process duration $(6 \mathrm{~h})$. Dependent variables are water loss (WL), solute gain (SG), and weight reduction (WR). After osmosis the slice samples were weighed by electrical balance. The weighed Fig samples were spread in the form of thin layer on aluminum trays. These aluminum trays were put in tray dryer at temperature of 50 
${ }^{\circ} \mathrm{C}$ for $9 \mathrm{~h}$. The tray dryer essentially having a cabinet into which the material to be dried is placed on trays. Mainly consist of a thermostat, fan \& temperature controller. The tray dryer having 12 numbers of trays placed one above another. The drying condition are simply controlled \& readily changed. The air velocity in the tray dryer is $0.3-2.3 \mathrm{~m} / \mathrm{s}$.

\section{Determination of moisture content}

Samples of Fig fruit slices were taken in moisture boxes. The boxes were kept in a hot air oven at $105^{\circ} \mathrm{C}$ for $24 \mathrm{~h}$ then the moisture boxes were placed in desiccators for 5 minutes; the weights were measured by an electronic digital balance having an accuracy of $0.001 \mathrm{~g}$. The moisture content was determined and expressed in wet basis by using the following equation.

$$
\begin{gathered}
\text { Moisture content }(\% \text { wet basis })=\left(\frac{\text { Initial weight-Final weight }}{\text { Initial weight }}\right) \times 100 \\
\text { Moisture content on }(\% \text { dry basis })=\frac{\mathrm{MC}(\% \text { Wet basis })}{100-\mathrm{MC}(\% \text { Wet basis })} \times 100
\end{gathered}
$$

\section{Water loss}

Water loss is the quantity of water lost by food during osmotic dehydration. The water loss (WL) is defined as the net weight loss of the Fig fruit slice on initial weight basis and is estimated as [7]:

$$
\mathrm{WL}=\frac{W_{i} \times X_{i}-W_{t} \times X_{t}}{W_{i}} \times 100
$$

Solute gain

The solids from the osmotic solution get added to the samples during osmotic dehydration. The loss of water from the sample takes place in osmotic dehydration consequently it increases the solid content. The solid gain is the net uptake of solids by the slices on initial weight basis and computed using following expression [7]:

$$
\mathrm{SG}=\frac{W_{t}\left(1-X_{t}\right)-W_{i}\left(1-X_{i}\right)}{W_{i}} \times 100
$$

\section{Weight reduction}

It is determine by the following formula

$$
\mathrm{WR}=\frac{W_{i}-W_{t}}{W_{i}} \times 100
$$

Weight reduction $=$ Water loss - Solute gain

Where WL = Water loss ( $\mathrm{g}$ water/ $100 \mathrm{~g}$ initial mass of Fig fruit slices), \%;

$S G=$ Sugar gain ( $\mathrm{g} / 100 \mathrm{~g}$ initial mass of Fig fruit slices), \%;

$W_{t}=$ Mass of onion slices after time $t, g$;

$X_{t}=$ Water content as a fraction of mass of Fig fruit slices at time $t$;

$W_{i}=$ Initial mass of Fig fruit slices, $g$;

$\mathrm{X}_{\mathrm{i}}=$ Water content as a fraction of initial mass of Fig fruit slices.

\section{Result and Discussion}

Effect of solution concentration and immersion time on water loss and solid gain

The water loss and solid gain of Fig fruit slices were affected by different sugar solution concentrations and immersion time. Effect of sugar solution concentrations (30, 40 and $50{ }^{\circ} \mathrm{Bx}$ ) on percent water loss (\%) and solid gain (\%) of $10 \mathrm{~mm}$ thick Fig fruit slices at different immersion time (1 to $6 \mathrm{hr}$ ) is shown in [Table -1]. As percent sugar concentration increased, 'percent water loss' and 'percent solid gain' were increased but comparatively water loss (\%) is quite higher than solid gain (\%) at all solution concentrations. For $6 \mathrm{~h}$ osmosis period, highest water

\begin{tabular}{|c|c|c|c|c|c|c|}
\hline \multirow[b]{2}{*}{$\begin{array}{l}\text { Immersion } \\
\text { time (hr) }\end{array}$} & \multicolumn{2}{|c|}{$30 \circ \mathrm{Bx}$} & \multicolumn{2}{|c|}{$40 \circ \mathrm{Bx}$} & \multicolumn{2}{|c|}{$50^{\circ} \mathrm{Bx}$} \\
\hline & $\begin{array}{l}\text { Water } \\
\text { loss (\%) }\end{array}$ & $\begin{array}{l}\text { Solid } \\
\text { gain } \\
(\%)\end{array}$ & $\begin{array}{l}\text { Water } \\
\text { loss } \\
(\%)\end{array}$ & $\begin{array}{l}\text { Solid } \\
\text { gain } \\
(\%)\end{array}$ & $\begin{array}{c}\text { Water } \\
\text { loss } \\
(\%)\end{array}$ & $\begin{array}{l}\text { Solid } \\
\text { gain } \\
(\%)\end{array}$ \\
\hline 1 & 3.62 & 1.62 & 6.53 & 2.03 & 11.27 & 2.35 \\
\hline 2 & 3.82 & 1.82 & 7.15 & 2.65 & 12.81 & 3.81 \\
\hline 3 & 4.6 & 2.6 & 9.49 & 4.99 & 17.71 & 8.17 \\
\hline 4 & 4.8 & 2.8 & 11.3 & 6.8 & 19.63 & 10.63 \\
\hline 5 & 5.48 & 3.48 & 11.87 & 7.37 & 20.27 & 11.27 \\
\hline 6 & 7.64 & 5.64 & 12.26 & 7.76 & 20.72 & 11.72 \\
\hline
\end{tabular}
loss (\%) of 7.64, 12.26, and 20.72 and solid gain (\%) of 5.64, 7.76, and 11.72 at 30,40 and $50^{\circ} \mathrm{Bx}$ sugar solutions, respectively was observed.
Table-1 Effect of different sugar concentrations and immersion time on water loss and solid gain (\%) of Fig fruit

The regression (relationship) between the immersion time on water loss (\%) and solid gain (\%) at $30^{\circ}$ Bxsugar solution is shown in [Fig-1]. The regression line can be considered an acceptable estimation of the true relationship between immersion time and water loss or immersion time and solid gain. The regression coefficient $\left(R^{2}\right)$ values for polynomial fit $\left(R^{2}=0.952\right)$ was better because it is closer to 1 as compared to exponential $\left(R^{2}=0.920\right)$ and linear $\left(R^{2}=0.854\right)$ fit in between immersion time (hr) and water loss (\%). For relating immersion time (hr) and solid gain $(\%)$, the polynomial equation $\left(R^{2}=0.952\right)$ fits well as compared to exponential $\left(R^{2}=0.950\right)$ and linear $\left(R^{2}=0.854\right)$ fit. Similarly, regression (linear, polynomial and exponential) between the immersion time on water loss (\%) and solid gain (\%) at 40 and $50{ }^{\circ} \mathrm{Bx}$ sugar solution was derived and found similar results as in case of $30^{\circ} \mathrm{Bx}$ sugar solution concentration.
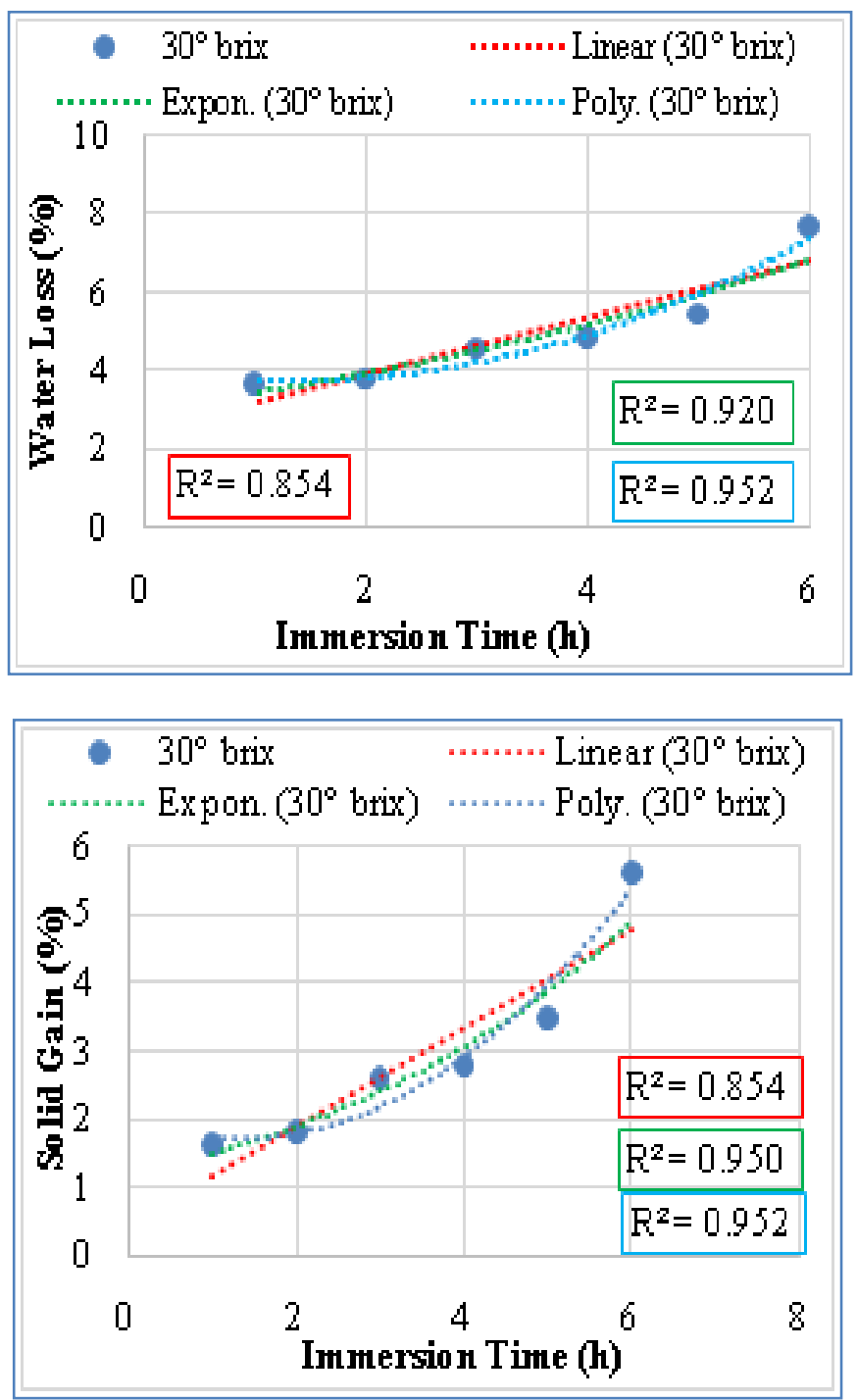

Fig-1 Effect of immersion time on water loss and solid gain of Fig fruit slices at $30^{\circ}$ Bxsugar solution 


\section{Effect of drying on weight reduction of Fig fruit slices at different sugar concentration}

The most important variable affecting the kinetics of mass transfer during osmotic dehydration is temperature [8]. During osmotic treatment, when temperature increased then loss of water and uptake of solid took place and increase in temperature of osmotic solution results in increases in water lose, whereas solid gain is less affected by temperature. In the literature of osmotic treatment, temperature around $50^{\circ} \mathrm{C}$ had been used for vegetables and fruits due to the subsequent reasons: 1) this reasonable temperature confined the deterioration of flavour, texture, and thermo sensible compounds of the materials, 2) enzymatic browning and flavour deterioration of fruits start at temperature of $49^{\circ} \mathrm{C}$, and 3 ) this temperature was also efficient to maintain the viscosity of the solution and adequate infusion time without changing the fruit quality[9].

Osmotically treated Fig fruit slices were dried in tray dryer at $50^{\circ} \mathrm{C}$ for $10 \mathrm{~h}$ at 30 ${ }^{\circ} \mathrm{Bx}$ sugar concentration. The weight reduction was calculated at different drying time intervals and data were analyzed. It was observed that the weight reduction was more rapid in first $4 \mathrm{~h}, 7 \mathrm{~h}$ and $8 \mathrm{~h}$ at 30,40 and $50^{\circ} \mathrm{Bx}$, respectively after that drying rate gradually decreased and almost reached a constant weight in sugar concentrations. Effect of sugar solution concentrations (30, 40 and $\left.50{ }^{\circ} \mathrm{Bx}\right)$ on moisture content $(\mathrm{db}, \%)$ and drying rate at different drying time (1-10 hr) is shown in [Table-2]. The moisture content at $30^{\circ} \mathrm{Bx}(\mathrm{db}, \%)$ was gradually starts reducing from $516.9(\%)$ at initial time (0 hr) to $159.89(\%)$ after $9 \mathrm{hr}$ and drying rate was reducing from 2.02 at initial time ( $1 \mathrm{hr})$ to 0.59 at $10 \mathrm{hr}$. The moisture content at 40 ${ }^{\circ} \mathrm{Bx}(\mathrm{db}, \%$ ) was gradually starts reducing from $517.64(\%)$ at initial time to 240.69 $(\%)$ at 580 minutes and drying rate was gradually reducing from 1.55 at initial time to 0.5 after 480 minutes. Similarly, the moisture content at $50{ }^{\circ} \mathrm{Bx}(\mathrm{db}, \%)$ was gradually starts reducing from $516.9(\%)$ at initial time to $255.08(\%)$ at 360 minutes and drying rate was gradually reducing from 0.3 at initial time to 0.12 after 360 minutes. It is concluded that the drying rate increases as the average moisture content (db, \%) increases.

Table-2 Effect of different sugar concentrations and drying time on moisture
content and drying rate of Fig fruit
\begin{tabular}{|c|c|c|c|c|c|c|}
\hline & \multicolumn{2}{c}{$40^{\circ} \mathrm{Bx}$} & \multicolumn{2}{c|}{$50^{\circ} \mathrm{Bx}$} \\
\hline $\begin{array}{c}\text { Drying } \\
\text { time } \\
(\mathbf{m i n})\end{array}$ & $\begin{array}{c}\text { Moisture } \\
\text { content } \\
(\mathrm{db})(\%)\end{array}$ & $\begin{array}{c}\text { Drying } \\
\text { rate } \\
(\%)\end{array}$ & $\begin{array}{c}\text { Moisture } \\
\text { content } \\
(\mathrm{db})(\%)\end{array}$ & $\begin{array}{c}\text { Drying } \\
\text { rate } \\
(\%)\end{array}$ & $\begin{array}{c}\text { Moisture } \\
\text { content } \\
(\mathrm{db})(\%)\end{array}$ & $\begin{array}{c}\text { Drying } \\
\text { rate } \\
(\%)\end{array}$ \\
\hline $0-0$ & 516.9 & & 517.64 & & 516.9 & \\
\hline $60-1$ & 395.28 & 2.02 & 424.31 & 1.55 & 422.88 & 0.3 \\
\hline $120-2$ & 314.86 & 1.68 & 367.45 & 1.25 & 360.59 & 0.25 \\
\hline $180-3$ & 270.89 & 1.36 & 335.49 & 1.01 & 333.47 & 0.19 \\
\hline $240-4$ & 233.78 & 1.17 & 302.15 & 0.89 & 302.54 & 0.17 \\
\hline $300-5$ & 206.97 & 1.03 & 277.25 & 0.8 & 276.27 & 0.15 \\
\hline $360-6$ & 184.90 & 0.92 & 263.72 & 0.73 & 255.08 & 0.14 \\
\hline $420-7$ & 168.07 & 0.83 & 240.69 & 0.65 & 255.08 & 0.12 \\
\hline $480-8$ & 162.02 & 0.73 & 240.69 & 0.5 & & \\
\hline $540-9$ & 159.89 & 0.66 & & & & \\
\hline $600-10$ & 159.89 & 0.59 & & & & \\
\hline \hline
\end{tabular}

Table-3 Effect of different sugar concentrations and drying time on moisture content and drying rate of Fig fruit

\begin{tabular}{|c|c|c|c|c|c|}
\hline \multicolumn{2}{|c|}{$30^{\circ} \mathrm{Bx}$} & \multicolumn{2}{c|}{$40^{\circ} \mathrm{Bx}$} & \multicolumn{2}{c|}{$50^{\circ} \mathrm{Bx}$} \\
\hline $\begin{array}{c}\text { Average } \\
\text { moisture } \\
\text { content(db) }\end{array}$ & $\begin{array}{c}\text { Drying } \\
\text { rate }\end{array}$ & $\begin{array}{c}\text { Average } \\
\text { moisture } \\
\text { content } \\
\text { (db) }\end{array}$ & $\begin{array}{c}\text { Drying } \\
\text { rate }\end{array}$ & $\begin{array}{c}\text { Average } \\
\text { moisture } \\
\text { content } \\
\text { (db) }\end{array}$ & $\begin{array}{c}\text { Drying } \\
\text { rate }\end{array}$ \\
\hline 159.85 & 0.59 & 240.69 & 0.5 & 255.08 & 0.12 \\
\hline 160.95 & 0.66 & 252.52 & 0.65 & 265.67 & 0.14 \\
\hline 165.04 & 0.73 & 270.48 & 0.73 & 289.4 & 0.15 \\
\hline 176.48 & 0.83 & 289.7 & 0.8 & 318 & 0.17 \\
\hline 195.93 & 0.92 & 318.82 & 0.89 & 347.03 & 0.19 \\
\hline 220.37 & 1.03 & 351.47 & 1.01 & 391.73 & 0.25 \\
\hline 252.87 & 1.17 & 395.88 & 1.25 & 469.89 & 0.3 \\
\hline 292.87 & 1.36 & 470.97 & 1.55 & & \\
\hline 355.07 & 1.68 & & & & \\
\hline 456.09 & 2.02 & & & & \\
\hline \hline
\end{tabular}

\section{Conclusions}

The osmotic dehydration of Fig fruit slices was done at different concentrations of sugar solution for a period of $6 \mathrm{hr}$ at an ambient temperature. The data was analyzed for determining the water loss, solid gain, and weight reduction and finally optimized to give a maximum water loss, weight reduction, and minimum solute gain. The water loss was observed more at $50 \%$ concentration $(20.72 \%)$ as compared to $40 \%(12.26 \%)$ and $30 \%(7.64 \%)$ sugar concentrations at ambient temperature. The solid gain was observed more at $50 \%$ sugar concentration (11.72\%) as compared to $40 \%(7.76 \%)$ and $30 \%(5.64 \%)$ sugar concentrations at ambient temperature. The weight reduction in tray drying in a drying period of $9 \mathrm{~h}$ at $50^{\circ} \mathrm{Ctemperatures} \mathrm{was} \mathrm{observed} \mathrm{i.e.} \mathrm{initially} \mathrm{drying} \mathrm{rate} \mathrm{was} \mathrm{more} \mathrm{up} \mathrm{to} 4 \mathrm{~h}$ of drying after then the drying rate was gradually decreased and almost reached a constant weight. It was concluded that the quality of osmotic dehydrated onion slices was best at $50 \%$ of sugar concentration.

\section{Application of research: Preservation of Fig Fruit}

Research Category: Process Engineering, Food Processing

Acknowledgement: Author are thankful to College of Agricultural Engineering, Acharya N.G. Ranga Agricultural University, Guntur, Bapatla, Andhra Pradesh 522101 and Vignan's Foundation for Science, Technology and Research, Vadlamudi, Guntur, Andhra Pradesh 522213, India

\section{*Research Guide: Sivala Kumar}

University: Acharya N.G. Ranga Agricultural University, Guntur, Bapatla, Andhra Pradesh 522101

Author Contributions: All author equally contributed.

Author statement: All authors read, reviewed, agree and approved the final manuscript

Conflict of Interest: No conflict of interest

Ethical approval: This article does not contain any studies with human participants or animals performed by any of the authors.

\section{References}

[1] Sutar N. and Sutar P.P. (2013) Trends in Post-Harvest Technology, 1(1), 20-36.

[2] Srivastava A., Adamala S. and Kumar S. (2016) Indian Journal of Ecology, 43(2), 533-536.

[3] Chavan U.D. and Amarowicz R. (2012) Journal of Food Research, 2(1), 202-209.

[4] Ahmed I., Qazi I.M. and Jamal S. (2016) Innovative Food Science \& Emerging Technologies, 34, 29-43.

[5] Prosapio V. and Norton N. (2017) LWT, 80, 401-408

[6] Ramya V. and Jain N. K. (2017) Journal of Food Process Engineering, 40(3), e12440.

[7] Akbarian M., Ghasemkhani N. and Moayedi F. (2014) International Journal of Biosciences, 4(1), $42-57$.

[8] Tortoe C. (2009) African Journal of Food Science 4(6), 303-324.

[9] Verma A.K., Rao P.S., Islam A. and Adamala S. (2017) Indian Journal of Ecology, 44(3), 618-627. 